(c) American Dairy Science Association, 2005.

\title{
The Association of Herd Milk Production and Management with a Return-Over-Feed Index in Ontario Dairy Herds
}

\author{
C. J. McLaren, ${ }^{1}$ K. D. Lissemore,${ }^{1}$ T. F. Duffield, ${ }^{1}$ K. E. Leslie, ${ }^{1}$ \\ D. F. Kelton, ${ }^{1}$ and B. Grexton ${ }^{2}$ \\ ${ }^{1}$ Department of Population Medicine, University of Guelph, \\ Guelph, Ontario, Canada N1G 2W1 \\ ${ }^{2}$ The Ontario Dairy Herd Improvement Corporation, \\ 660 Speedvale Avenue, Guelph, Ontario, Canada N1K 1E5
}

\begin{abstract}
Associations of herd milk production and management variables to a return-over-feed (ROF) herd profit index were examined among 95 dairy farms. The ROF index is derived from 2 important determinants of profit on dairy farms: milk income and feed cost. All producers were participants in the Dairy Herd Improvement (DHI) ROF program in Ontario, Canada during 2002. Nutrition, housing, health, and other management data were collected through a phone survey of herd managers. Herd milk production, milk component percentages, and somatic cell count data were obtained from the Ontario DHI database. The linear regression model accounting for significant variation in ROF with highest $\mathrm{R}^{2}$ (0.66) included standardized milk production, milk protein percentage, milk fat percentage, and use of monensin in lactating cow rations. A 1-kg increase in standardized milk production (kg/d per cow) or a 0.1 percentage unit increase in milk protein was associated with $\$ 0.35 / \mathrm{d}$ per cow or $\$ 0.26 / \mathrm{d}$ per cow increase, respectively, in the ROF of the dairy herd. However, a 0.1 percentage unit increase in milk fat was associated with a $\$ 0.10 / \mathrm{d}$ per cow decrease in ROF, probably because of a negative association of milk fat with milk yield. Use of monensin in lactating cow rations was associated with a $\$ 0.39 / \mathrm{d}$ per cow increase in ROF. In a separate model $\left(R^{2}=0.27\right)$ that examined management factors independent of production variables, herds using 3 times daily milking had a $\$ 1.25 / \mathrm{d}$ per cow higher ROF vs. herds using twice daily, whereas use of an Escherichia coli mastitis vaccine was associated with $\$ 0.59 /$ $\mathrm{d}$ per cow higher ROF. Production-related variables accounted for more variation in the ROF index than management variables, and the latter, e.g., use of monensin,
\end{abstract}

Received April 13, 2004.

Accepted September 7, 2004.

Corresponding author: C. McLaren; e-mail: mclarenc@uoguelph. only marginally increased $R^{2}$ of production-based regression models.

(Key words: return over feed, milk production, management, economics)

Abbreviation key: CRC = controlled-release capsule, ROF $=$ return over feed.

\section{INTRODUCTION}

Research in dairy production management has focused on the effect that management has on both milk production and disease status of the individual animal. The effect of housing on lameness and mastitis has been reported in many studies throughout the world (Dohoo et al., 1984; Shearer, 1998). Environmental and nutritional conditions have been reported to be associated with many periparturient diseases, such as displaced abomasum, lameness, milk fever, and ketosis (Erskine, 2001). Studies have also shown the effect that these disease conditions have on reduced herd milk production (Lucey et al., 1986). In addition, multiple studies have reported the effect that 3 times daily milking has on overall herd milk production (Allen et al., 1986; Smith et al., 2002). Further research has shown the effect that additives such as monensin, vitamin $\mathrm{E}$, and selenium have on increased milk production (Hurley and Doane, 1989; Duffield et al., 2002). Despite the effect that management can have on milk production and disease, there have been few studies to investigate the relationship of these management factors on the profitability of the dairy farm. In addition, limited studies have shown the impact of herd production variables on the overall profitability of the farm.

It has been reported in previous studies that the 2 most important determinants of profitability on dairy farms are milk income and feed cost (Adkinson et al., 1993; de Araujo and de Vries, 2003). Because of this relationship, in 1998, Ontario DHI began calculating the difference in these measures, called return over feed (ROF). This monthly value is calculated based on daily milk produced and feed consumed per cow. 
Monetary values are generated using the Ontario Multiple Component Pricing system for milk and provincial average cost of feed ingredients (Dairy Farmers of Ontario, 2002).

To date, there have been no studies examining the relationship between herd management and the ROF index in Ontario dairy farms. The objective of this study was to quantify the effect that management can have on farm profit, as measured by ROF, so that further strategies can be proposed to take advantage of these relationships.

\section{MATERIALS AND METHODS}

\section{Data Collection}

The dairy farms involved in this study were participants in the ROF clubs administered through Ontario DHI. Herds were selected based on their willingness to participate in this study between January 1, 2002 and January 31, 2003. Only herds enrolled with Ontario DHI that also subscribed to the individual cow SCC option were included in the study. In addition, herds that actively participated in the ROF program for at least 3 mo during the study period were eligible.

Monthly herd production variables of standardized daily milk production, herd fat and protein percentage, and SCC linear score were obtained from the DHI monthly test data. Standardized milk production is calculated by DHI as the daily milk yield adjusted to the yield of a cow during her second lactation at 150 DIM in each herd.

Values for ROF were determined based on milk production and feed intake per cow per day for each month during the period of January 1, 2002 through January 31,2003 . Herd level DMI was determined through individual producer submissions of the amounts (per cow per day) of each feed ingredient in the lactating cow ration for each month. In addition, the percentage of DM of each corresponding feed ingredient, as determined through regular feed analysis as part of on-farm ration formulation, was collected for each month. This information was then used to calculate feed cost each month using provincial average feed prices (Ontario DHI, 2002). Milk income was calculated using the Dairy Farmers of Ontario Multiple Component Pricing formula (fat: $\$ 5.819 / \mathrm{kg}$, protein: $\$ 9.139 / \mathrm{kg}$, other solids: $\$ 1.318 / \mathrm{kg}$ ) (Dairy Farmers of Ontario, 2002). The difference between milk income and feed cost was the ROF index for the month. The ratio of forage and concentrate DMI was calculated from the feed ingredient and composition submissions made for the calculation of the ROF index.

A survey, designed to capture data about herd management factors affecting the ROF index, was adminis- tered by telephone. The survey included questions regarding the nutrition, housing, and health management practices used on participants farms.

\section{Data Management and Statistical Analyses}

A relational database was created (Access, Microsoft Corporation, 1997) to store the management variables, ROF, and production data. The data were imported into SAS (SAS Institute Inc., 1997) for analyses. All data were merged based on the Ontario DHI herd identification number. Initially, an ANOVA was performed using PROC ANOVA, examining the ROF index to determine the within and between herd variation of ROF. This operation was performed to collapse the information into one value for each herd. Significant variation between herds was set at $P \leq 0.05$.

The distributions of ROF and proposed risk factors were examined by descriptive and univariate analyses using PROC MEANS and PROC REG, respectively. Collinearity and leverage were examined using the variance inflation factor and graphical analysis, respectively. A liberal $P$ value of $<0.20$ and the biological significance of the variable were used as criteria for inclusion in model building procedures. To understand relationships between management factors and standardized milk production, a linear regression model (PROC REG) was used.

A best subsets analysis using PROC GLMMOD was performed, including variables with suitable distributions (determined in the univariate procedure) that could be conceivably related to the ROF index. This modeling procedure also considered all biologically plausible interaction terms. This procedure was performed for the production and management variables separately, as well as together, to understand the association of these variables with ROF. For each analysis, both Mallows $\mathrm{C}(P)$ and the adjusted $\mathrm{R}^{2}$ were examined to determine which model was the most suitable for the variables of interest. Each plausible model and the associated variables were then incorporated into PROC REG, where residual analysis and the Shapiro-Wilk test for normality were used to assess the models. Variables that were not significant at $P \leq 0.05$ were removed manually, one at a time, until all remaining variables had a $P$ value of $\leq 0.05$. The final model for both production and management variables, as well as the combined model, included variables and interaction terms having a statistically significant $(P \leq 0.05)$ association with ROF.

\section{RESULTS}

For the period of January 1, 2002 to January 31, 2003, there were 356 producers throughout Ontario 
Table 1. Summary of continuous herd level explanatory variables from 95 dairy herds in Ontario.

\begin{tabular}{lcccc}
\hline Variable & Mean & $\begin{array}{c}\text { Standard } \\
\text { deviation }\end{array}$ & Minimum & Maximum \\
\hline Return over feed (\$/d per cow) & 12.95 & 1.4 & 9.70 & 15.89 \\
Feed cost (\$/d per cow) & 3.92 & 0.4 & 2.73 & 5.03 \\
Milk revenue (\$/d per cow) & 16.89 & 1.5 & 13.46 & 20.68 \\
Herd average linear score & 2.8 & 0.4 & 1.8 & 3.8 \\
Herd average standardized milk production & & & & \\
(kg/d per cow) & 32.8 & 3.1 & 25.3 & 40.5 \\
Herd average milk fat percentage & 3.7 & 0.3 & 2.9 & 5.2 \\
Herd average milk protein percentage & 3.2 & 0.1 & 3.0 & 3.9 \\
Average herd size & 76.2 & 48.7 & 28 & 340 \\
Percentage forage DM in the diet & 53.7 & 4.9 & 43.9 & 68.4 \\
\hline
\end{tabular}

participating in the Ontario DHI ROF program that were introduced to the herd management study. From these producers, there were 95 herds (26.7\%) that volunteered and had useable information from the ROF, production, and management data sources (Holstein = $96.8 \%[\mathrm{n}=92]$, Jersey $=2.1 \%[\mathrm{n}=2]$, Holstein/Brown Swiss $=1.1 \%[\mathrm{n}=1])$.

The variance observed for the ROF values revealed that there was more variation $(P<0.0001)$ between than within herds. Therefore, one average ROF value for each participating farm was used for the study. The distribution of the ROF, feed cost, and total revenue of the herds is summarized in Table 1. The mean herd size for the duration of the study was approximately 76 cows. The mean herd SCC linear score, standardized milk production, fat percentage, and protein percentage were $2.8,32.8 \mathrm{~kg} / \mathrm{d}, 3.7 \%$, and $3.2 \%$, respectively (Table 1). Descriptive aspects of selected nutrition, housing, and health management information are summarized in Table 2.

The univariate analysis for the continuous and dichotomous proposed factors revealed that average herd size, 3 times vs. twice daily milking, TMR use, and immunization with an Escherichia coli mastitis vaccine tended to be positively $(P<0.20)$ associated with herd ROF. In addition, monensin use as a controlled release capsule (CRC) and as a lactating cow ration addition tended to be positively $(P<0.20)$ associated with ROF in the initial univariate analysis. Conversely, the ration forage-to-concentrate ratio was negatively associated $(P<0.05)$ with the ROF index. Lactating cow facility type was not associated with the ROF index in this group of herds. Herd protein percentage, 3 times daily milking, use of an $E$. coli mastitis vaccine, and monensin use as a CRC and lactating ration additive were positively associated $(P<0.05)$ with herd standardized

Table 2. Summary of responses and descriptive statistics for the management survey for nutrition, housing, and health management characteristics of study participants.

\begin{tabular}{|c|c|c|c|c|c|}
\hline Proposed risk factor & Category & $\begin{array}{l}\text { Herds } \\
\text { (no.) }\end{array}$ & $\begin{array}{l}\text { Mean ROF } \\
(\$ / d \text { per cow })\end{array}$ & $\begin{array}{l}\text { Mean } \\
\text { standardized }^{1} \\
\text { production } \\
\text { (kg/d per cow) }\end{array}$ & $\begin{array}{l}\text { Mean } \\
\text { herd } \\
\text { size }\end{array}$ \\
\hline \multirow[t]{2}{*}{ Loose housing facility ${ }^{2}$} & Yes & $40(42.1 \%)$ & $\$ 13.09$ & 33.0 & 106.0 \\
\hline & No & $55(57.9 \%)$ & $\$ 12.86$ & 32.6 & 54.5 \\
\hline \multirow[t]{2}{*}{3 milkings/d } & Yes & $11(11.6 \%)$ & $\$ 14.40$ & 36.6 & 107.1 \\
\hline & No & $84(88.4 \%)$ & $\$ 12.76$ & 32.3 & 72.2 \\
\hline \multirow{2}{*}{$\begin{array}{l}\text { Monensin: lactating } \\
\text { cow ration }\end{array}$} & Yes & $38(40.0 \%)$ & $\$ 13.39$ & 32.3 & 70.4 \\
\hline & No & $57(60.0 \%)$ & $\$ 12.66$ & 33.5 & 85.0 \\
\hline \multirow{2}{*}{ Monensin: dry cow ration } & Yes & $17(17.9 \%)$ & $\$ 12.73$ & 31.9 & 63.8 \\
\hline & No & $78(82.1 \%)$ & $\$ 13.00$ & 33.0 & 78.9 \\
\hline \multirow[t]{2}{*}{ Monensin $\mathrm{CRC}^{3}$ used } & Yes & $52(54.7 \%)$ & $\$ 13.22$ & 33.3 & 82.9 \\
\hline & No & $43(45.3 \%)$ & $\$ 12.63$ & 32.1 & 68.1 \\
\hline \multirow[t]{2}{*}{ TMR use } & Yes & $79(83.2 \%)$ & $\$ 13.09$ & 32.9 & 81.6 \\
\hline & No & $16(16.8 \%)$ & $\$ 12.29$ & 32.0 & 49.4 \\
\hline \multirow{2}{*}{$\begin{array}{l}\text { Vitamin } \mathrm{E} \text { administered } \\
\text { to dry cows }\end{array}$} & Yes & $20(21.1 \%)$ & $\$ 13.28$ & 33.5 & 67.1 \\
\hline & No & $75(78.9 \%)$ & $\$ 12.86$ & 32.6 & 78.6 \\
\hline \multirow{2}{*}{$\begin{array}{l}\text { Escherichia coli mastitis } \\
\text { vaccination }\end{array}$} & Yes & $40(42.1 \%)$ & $\$ 13.47$ & 34.1 & 90.2 \\
\hline & No & $55(57.9 \%)$ & $\$ 12.58$ & 31.8 & 66.0 \\
\hline
\end{tabular}

${ }^{1}$ Standardized to yields at 150 DIM for second lactation cows.

${ }^{2}$ Bedded pack and freestall facilities.

${ }^{3} \mathrm{CRC}=$ Controlled-release capsule. 
Table 3. Final linear regression model describing the relationship between various milk production factors and return over feed. ${ }^{1}$

\begin{tabular}{llc}
\hline & $\begin{array}{l}\text { Parameter } \\
\text { estimate } \\
\text { (\$/d per cow) }\end{array}$ & $P$ \\
\hline Production variable & -2.64 & 0.36 \\
Intercept & 0.36 & $<0.0001$ \\
$\quad$ (kg/d per cow) & & 0.007 \\
Herd average milk fat percentage & -0.93 & 0.015 \\
\hline
\end{tabular}

${ }^{1}$ Squared multiple correlation coefficient $\left(\mathrm{R}^{2}=0.64\right)$ for the 3 milk production factors shown that account for significant variation in return over feed costs.

${ }^{2}$ Standardized to yields at 150 DIM for second-lactation cows.

milk production. Herd average fat percentage and ration forage-to-concentrate ratio were associated with decreases $(P<0.05)$ in the herd standardized milk production.

The final linear regression coefficients for the production and management models are summarized in Tables 3 and 4, respectively. Both milk production and milk protein percentage were positively associated with ROF, whereas milk fat percentage was negatively associated with the index (model $\mathrm{R}^{2}=0.64$ ). In the management survey analysis, only 3 times daily milking, monensin fed to lactating cows and as a CRC, and use of an $E$. coli mastitis vaccine remained in the final regression model $\left(R^{2}=0.27\right)$, and all of those variables had a positive association with the ROF index. However, ration forage-to-concentrate ratio was not selected in the final models. The summary of the final model is shown in Table 5 and includes all of the originally selected production variables, as well as monensin fed to the lactating animal (model $R^{2}=0.66$ ). Increased milk fat and milk protein percentage were associated with a decrease and increase in ROF, respectively.

\section{DISCUSSION}

The analytic approach used in this study involved the separate and combined inclusion of production and

Table 4. Final linear regression model describing the relationship between various management factors and return over feed. ${ }^{1}$

\begin{tabular}{lll}
\hline & $\begin{array}{l}\text { Parameter } \\
\text { estimate } \\
\text { Management variable }\end{array}$ & \\
\hline Intercept & 11.95 & $<0.0001$ \\
Escherichia coli mastitis vaccination & 0.60 & 0.02 \\
3 milkings/d & 1.25 & 0.002 \\
Monensin in lactating cow ration & 0.69 & 0.01 \\
Monensin controlled-release capsule & 0.61 & 0.02 \\
\hline
\end{tabular}

\footnotetext{
${ }^{1}$ Squared multiple correlation coefficient $\left(\mathrm{R}^{2}=0.27\right)$ for the 4 management factors shown that account for significant variation in return over feed costs.
}

management variables with ROF. This method allowed the elucidation of the relationship of each variable with the ROF index. This study supports previous research indicating that one of the most important factors associated with profitability is milk production. It has been reported that 80 to $95 \%$ of the income on dairy farms is derived from milk sales (Adkinson et al., 1993; Ontario Dairy Farm Accounting Project, 2002; de Araujo and de Vries, 2003). In addition, previous studies have reported that 3 times daily milk harvesting was associated with significant increases in milk production (Allen et al., 1986; Smith et al., 2002). From the current study, 3 times daily milking was associated with an increase in ROF of $\$ 1.25 / \mathrm{d}$ per cow. This effect may be from the increased milk production evident in the 3 times daily milking group. In addition, these herds might have had additional management that contributed to this observation.

The effect of volume and milk components on milk income was illustrated in this study by these variables remaining in all production models. Overall, a 1-kg increase in milk production was associated with a $\$ 0.35 /$ d per cow increase in ROF (Table 5). Similarly, with a 0.1 -percentage point increase in protein percentage, ROF was increased by $\$ 0.23$ to $\$ 0.26 / \mathrm{d}$ per cow. This association may be linked to the increase in milk income derived from the Multiple Component Pricing formula in Ontario with a gain in protein percentage (Dairy Farmers of Ontario, 2002).

A 0.1-percentage point increase in milk fat percentage decreases the ROF index by approximately $\$ 0.10 /$ $\mathrm{d}$ per cow. This association may be due to the marginally significant production decrease found in herds with higher fat percentage. The reduced milk volume may decrease overall milk income and ROF for that herd. The reduction in herd standardized milk production can be related to a number of herd management factors. A highly fibrous diet would likely increase the milk fat percentage of the herd (Gerloff, 2001). However, this diet would decrease the passage of forage from the ru- 
Table 5. Final linear regression model describing the relationship between various production and management factors and return over feed. ${ }^{1}$

\begin{tabular}{lcc}
\hline & $\begin{array}{l}\text { Parameter } \\
\text { estimate } \\
\text { Variable }\end{array}$ & $P$ per cow $)$ \\
\hline Intercept & -3.60 & 0.21 \\
Herd average standardized milk production (d per cow) & 0.35 & $<0.0001$ \\
Herd average milk fat percentage & -0.97 & 0.004 \\
Herd average milk protein percentage & 2.62 & 0.005 \\
Monensin in lactating cow ration & 0.39 & 0.026 \\
\hline
\end{tabular}

${ }^{1}$ Squared multiple correlation coefficient $\left(\mathrm{R}^{2}=0.66\right)$ for the 4 production and management variables shown that account for significant variation in return over feed costs.

men, reduce DMI, and may reduce the overall milk production. Conversely, a highly digestible ration (higher proportion of grain) would increase the DMI and the subsequent milk production. The significant negative association of herd milk production and forage-to-concentrate ratio found in this study supports this. When monensin use is added to the model, there is a change in the fat $(0.1 \%$ increase $)$ coefficient from a loss of $\$ 0.09$ to $\$ 0.10 / \mathrm{d}$ per cow. This may be related to the reported reduction in milk fat percent when monensin is fed (McGuffey et al., 2001). Therefore, when this feed additive is accounted for in the model, herds with high milk fat still have lower production and, thus, lower ROF.

In the original univariate procedure, herd SCC linear score was negatively associated with ROF. However, in the linear regression model, SCC linear score was not selected by the best subsets procedure. There might not have been sufficient herd milk production losses in the current study to yield a statistically significant reduction in ROF with elevated herd SCC linear score.

The finding that housing type was not associated with an increase in the ROF index is contrary to the findings of a recent study (Bewley et al., 2001). That recent study was a random survey sample study of over 300 Wisconsin dairy herds. The sample of herds that was used in the current ROF study was not a random sample of herds. These herds were selected from volunteers in a management club provided through Ontario DHI, and management and production may be much different than in the typical Ontario dairy population. Furthermore, there was not a significant production difference between housing types. Therefore, based on the reported association of milk production and ROF, one would not expect an association of ROF with housing type. The number of farms in this study might not be sufficient to detect a difference in ROF for loose housing facilities (Table 2).

In the current study, use of an $E$. coli mastitis vaccine was positively associated with ROF. In addition, this practice was associated with a larger herd size (Table
$2)$. Use of this vaccine is associated with a reduction in the coliform mastitis severity following parturition (Yancey, 1999). It has been reported that mastitis before 120 DIM is associated with a reduction in milk production (Lucey and Rowlands, 1984; Rajala-Schultz et al., 1999). Therefore, the use of an $E$. coli vaccine against mastitis might have reduced the severity of coliform mastitis and the subsequent production losses in early lactation. This hypothesis was supported by the increase in production associated with use of a mastitis immunization program in this study. In addition, the increase in the ROF value of $\$ 0.59 / \mathrm{d}$ per cow in the management model was not evident when milk production was accounted for in the analysis.

The use of monensin in the lactating ration was positively associated with an increased ROF of $\$ 0.69 / \mathrm{d}$ per cow. However, when milk production variables were included in the analysis, the magnitude of this coefficient was reduced to $\$ 0.39 / \mathrm{d}$ per cow. In addition, monensin use was significantly correlated with herd production in a simple univariate analysis. This observed effect may be due to the tendency for these herds to use monensin for ketosis prevention. Herds that are more at risk for ketosis are the higher producing herds, which have followed instructions from their advisors to use monensin to reduce the ketosis in the herd. Production could also be a factor because it has been reported that cows yield 0.85 to $1.25 \mathrm{~kg} / \mathrm{d}$ more milk when administered a monensin CRC precalving (Duffield et al., 1999). The beneficial effect of monensin fed to the lactating animal may be related to impacts on milk fat, milk production, DMI, and, hence, milk production efficiency observed in recent research (Van der Werf et al., 1998; Green et al., 1999; Symanowski et al., 1999; Phipps et al., 2000).

The use of monensin in the dry cow diet had no effect on the ROF index. This may be due to this ration only having effects on the dry cow, and ketosis prevention would be expected to require both dry and lactating supplementation. Furthermore, the ROF index used in the current research is measuring the milk production 
and feed cost of the lactating herd. Therefore, the use of the lactating ROF as an indicator of the usefulness of dry cow practices may not be appropriate in this situation. It may be necessary to view dry cow management in the context of dry cow ROF values.

The positive association of monensin $\mathrm{CRC}$ with $\mathrm{ROF}$ was evident when management variables were included in the model. This association may be due to the reduction in metabolic diseases and increased production that has been found with the use of the CRC (Duffield et al., 2002). This was supported by the marginally significant relationship of CRC use and standardized milk production. However, the increase of $\$ 0.61 / \mathrm{d}$ per cow observed in the management model was not evident when production was included in the model. This may be due to this form of monensin only having effects for $95 \mathrm{~d}$. If the capsule is given at $21 \mathrm{~d}$ prepartum, there may be only direct lactation affects for $74 \mathrm{~d}$. Adding production to the model appears to account for most of the CRC effects, suggesting that a reduction in subclinical and clinical metabolic disease results in milk production benefits. In addition, there might not have been sufficient statistical power to detect a difference in ROF values that were observed in the descriptive results in Table 2.

\section{CONCLUSIONS}

The results of this study indicate that milk production has a strong positive association with the ROF of the individual dairy herd. Similarly, 3 times daily milking has a positive association with the ROF of herds. However, with production variables added to the model, this variable is no longer significant and the direct measure of production remains. The ROF index is also affected by the component percentages in the herd milk test. Increasing milk fat percentage has a negative association with the ROF index, whereas milk protein increases are positively associated with ROF. Use of an $E$. coli mastitis vaccine was associated with increased ROF in the study herds. Monensin used as an additive to the lactating diet was positively associated with the ROF index, not only in the management model but also when production was included in the analysis. Controlled-release capsule delivery of monensin was positively associated with ROF in the management model, but when production was added, it did not remain in the model.

\section{ACKNOWLEDGMENTS}

The authors thank the dairy producers who participated in the study for the valuable information that they provided. Ontario DHI staff, employees, and ROF club leaders support of this project is greatly appreciated. Financial support for this observational study was provided through Elanco Animal Health Inc., the Ontario Ministry of Agriculture and Food, Sanwa Kagaku Kenkyusho Co. Ltd., and the Natural Sciences and Engineering Research Council of Canada.

\section{REFERENCES}

Adkinson, R. W., W. S. Farmer, and B. F. Jenny. 1993. Feeding practices and income over feed cost on pasture-oriented dairy farms in Louisiana. J. Dairy Sci. 76:3547-3554.

Allen, D. B., E. J. DePeters, and R. C. Laben. 1986. Three times a day milking: Efects on milk production, reproductive efficiency, and udder health. J. Dairy Sci. 69:1441-1446.

Bewley, J., R. W. Palmer, and D. B. Jackson-Smith. 2001. A comparison of free-stall barns used by modernized Wisconsin dairies. J. Dairy Sci. 84:528-541.

Dairy Farmers of Ontario. 2002. Pages 1-46 in Dairy Farmers of Ontario Policies: Quota, Milk Quality, Farm Yards and Lanes. Dairy Farmers of Ontario, Mississauga, ON, Canada.

de Araujo, A. E. M., and A. de Vries. 2003. Ranking of dairy farms based on economic measures per cwt milk sold and per cwt milk equivalent. J. Dairy Sci. 82(Suppl. 1):358.

Dohoo, I. R., S. W. Martin, and A. H. Meek. 1984. Disease, production and culling in Holstein-Friesian cows. VI. Effects of management on disease rates. Prev. Vet. Med. 3:15-28.

Duffield, T., R. Bagg, L. DesCoteaux, E. Bouchard, M. Brodeur, D. DuTremblay, G. Keefe, S. LeBlanc, and P. Dick. 2002. Prepartum monensin for the reduction of energy associated disease in postpartum dairy cows. J. Dairy Sci. 85:397-405.

Duffield, T. F., K. E. Leslie, D. Sandals, K. Lissemore, B. W. McBride, J. H. Lumsden, P. Dick, and R. Bagg. 1999. Effect of prepartum administration of monensin in a controlled-release capsule on milk production and milk components in early lactation. J. Dairy Sci. 82:272-279.

Erskine, R. J. 2001. Mastitis control in dairy herds. Pages 397-436 in Herd Health: Food Animal Production Medicine. 3rd ed. O. M. Radostits, ed. W. B. Saunders Company, Toronto, Canada.

Gerloff, B. J. 2001. Dairy Cattle Nutrition. Pages 435-473 in Herd Health: Food Animal Production Medicine. 3rd ed. O. M. Radostits, ed. W. B. Saunders Company, Toronto, Canada.

Green, H. B., J. T. Symanowski, J. I. D. Wilkinson, J. S. Davis, R. Himstedt, M. S. Allen, E. Block, J. J. Brennan, H. H. Head, J. J. Kenelly, J. N. Nielsen, J. E. Nocek, M. J. Van Der List, and L. W. Whitlow. 1999. Effect of monensin on feed intake, body weight, and body condition in dairy cows. J. Dairy Sci. 82(Suppl. 1):75.

Hurley, W. L., and R. M. Doane. 1989. Recent developments in the roles of vitamins and minerals in reproduction. J. Dairy Sci. 72:784-804.

Lucey, S., and G. J. Rowlands. 1984. The association between clinical mastitis and milk yield in dairy cows. Anim. Prod. 39:165-175.

Lucey, S., G. J. Rowlands, and A. M. Russell. 1986. Short-term associations between disease and milk yield of dairy cows. J. Dairy Res. $53: 7-15$.

McGuffey, R. K., L. F. Richardson, and J. I. D. Wilkinson. 2001. Ionophores for dairy cattle: Current status and future outlook. J. Dairy Sci. 84(Suppl. E.):E194-E203.

Ontario Dairy Farm Accounting Project. 2002. Subject: Ontario Dairy Farm Accounting Project Publication. http://www.milk.org/pdf/ publications-odfap_report.pdf. Accessed Nov. 26, 2003.

Ontario DHI. 2002. Return Over Feed and Management Club Producer Manual. Ontario DHI Corporation, Guelph, Ontario, Canada.

Phipps, R. H., J. I. D. Wilkinson, L. J. Jonker, M. Tarrant, A. K. Jones, and A. Hodge. 2000. Effect of monensin on milk production of Holstein-Friesian dairy cows. J. Dairy Sci. 83:2789-2794.

Rajala-Schultz, P. J., Y. T. Grohn, C. E. McCulloch, and C. L. Guard. 1999. Effects of clinical mastitis on milk yield in dairy cows. J. Dairy Sci. 82:1213-1220. 
SAS Institute Inc. 1997. SAS/STAT Software: Changes and Enhancements Through Release 6.12, SAS Inst., Inc., Cary, NC.

Shearer, J. K. 1998. Lameness of dairy cattle: Consequences and causes. Bovine Pract. 32:79-85.

Smith, J. W., L. O. Ely, W. M. Graves, and W. D. Gilson. 2002. Effect of milking frequency on DHI performance measures. J. Dairy Sci. 85:3526-3533.

Symanowski, J. T., H. B. Green, J. R. Wagner, J. I. D. Wilkinson, J. S. Davis, M. R. Himstedt, M. S. Allen, E. Block, J. J. Brennan,
H. H. Head, J. J. Kennelly, J. N. Nielsen, J. E. Nocek, J. J. Van Der List, and L. W. Whitlow. 1999. Milk production and efficiency of cows fed monensin. J. Dairy Sci. 82(Suppl. 1):75.

Van der Werf, J. H., L. J. Jonker, and J. K. Oldenbroek. 1998. Effect of monensin on milk production by Holstein and Jersey cows. J. Dairy Sci. 81:427-433.

Yancey, R. J. 1999. Vaccines and diagnostic methods of bovine mastitis: Fact and fiction. Adv. Vet. Med. 41:257-273. 